\title{
Can Science Develop Creativity in Early Children?
}

\author{
Nina Permata Sari ${ }^{1 *}$, Muhammad Andri Setiawan², and Eklys Cheseda Makaria ${ }^{3}$ \\ ${ }^{123}$ Lambung Mangkurat University \\ *Corresponding author. Email: nina.bk@ulm.ac.id
}

\begin{abstract}
Today society needs people who are not only smart but also creative as a form of actualization towards a dignified nation, therefore the writing in this article collects various literacy sources and includes all available written and digital sources related to how to develop creativity through science. Creativity is an important aspect to be developed in individuals because it is a reflection of self-manifestation in creative thinking, the creative side exists in humans, but stimulation and support from internal and external factors can give results in the development or failure of creativity in each individual. For this reason, cultivating the spirit of creativity from an early age in children is a must for educators in preparing creative generations for the future. Various ways can be done to stimulate the development of creativity, one of which is to include scientific concepts in the learning and play process, effective science activities in developing children's creativity, including playing exploration and experimenting by utilizing the surrounding environment, developing creativity through science can teach children to respect and love nature more.
\end{abstract}

Keywords: "Creativity", "Early Childhood", "Science"

\section{INTRODUCTION}

All children who are born into the world have been perfected with various abilities, one of which is the creative ability or the ability to create. It's just that, creativity skills will not develop properly without a supportive environment and help from the people around them. For this reason, it requires the development of creativity that can provide the best service for all aspects of early childhood development [15]. Children who can create are creative. Creative children can produce unique, original, and interesting works from their thinking power. The resource of thought is the knowledge that is transferred to children, this is the main support in developing creativity in children, besides that it is also the direct experience that children get in their lives [12], [9], [8].

Early childhood education is a very important educational provision in the early life of a child, as a foundation and foundation for children to prepare for future life. thus, the government made early childhood education institutions a priority in creating education in Indonesia. The main purpose of education is basically to stimulate the abilities of children from childhood and become prepared for life and be able to fit in with the environment [19], [10], [5]. Early childhood generally has the potential for talent and creativity that they are born with, be it potential in the arts or other fields, this can make children have more value for themselves, even though each child has characteristics and has its advantages.
Creative thinking can be considered as one of the key competencies for the 21st century. Enable humans to fly to the moon, create art, develop technology and cure various diseases. Creativity has been recognized as very helpful in the fields of science and art, besides playing an important role in solving everyday problems [17]. Nature is so rich in knowledge that it can inspire an educator to package interesting lessons that can stimulate children's creative power, such as doing simple science learning activities by observing, exploring, and experimenting with the surrounding environment. Increasing insight into thinking in individuals is influenced by the brain that has creative ideas.

Considering the importance of the development of creativity in early childhood, an educator needs to make efforts to prepare a quality successor of the nation, as a provision for entering this era of globalization which is full of challenges, in other words, success in the future can only be created through means. preparing the current generation through the early childhood education learning that can stimulate every child's growth and development and under the early childhood learning criteria. So that the purpose of this study is to get an idea of whether science can develop creativity in early childhood.

\section{METHODOLOGY}

The qualitative approach using the library method (library research) which is the object of this research is 
that scientific theory can develop creativity in children, where the data are taken comes from observation and extracting documents, such as using books, articles, stories historical stories as the data source of this research. The researcher performed the analysis using content analysis, the data obtained from the library research were analyzed to obtain a conclusion that was valid and relevant to the research conducted. Content analysis is a method used in getting the conclusion from research using message characteristics that are carried out in an actual and systematic manner [14].

\section{DISCUSSION}

Creativity is a form of actualization and manifestation of each individual, with a person's creative potential which can provide benefits not only to himself but also to his environment [9]. Also, creativity is an individual's ability to create something new, which can be translated into ideas, ideas, or works [17]. Legget [13] defines that creativity for children involves cognitive processes that develop through social interaction, play, and imagination. Creative thinking is a transformative activity that leads to ways of thinking and the creation of new products for children that are beneficial to their environment. This definition challenges the existing definition which assumes that early childhood is not yet capable of being creative [11].

In line with that, [7] creativity as a person's ability to produce something that can be said to be new, either in the form of ideas or real works that are relatively different from what already exists. Another opinion states that creativity is an ability that reflects the fluency, flexibility, and originality of an idea [2]. From some of the opinions above, it can be concluded that creativity is a person's ability to create or create new things, which have never existed before, whether in the form of ideas or through working cubits (product creation).

Creativity needs to be nurtured from an early age because; (1) creativity is a need for individuals to exist and survive in their environment, (2) creativity is not static, meaning that creativity is not limited, but creativity can be explored and developed with various stimuli, (3) humans need directed education and freedom to act without restraint in realizing each of his ideas, (4) creativity to hone human talents and abilities in facing life's problems and needs or even the progress of a nation [9]. Creativity that is started or developed early will be stable in adolescence, even some experts believe that children are the real manifestation of creativity. For this reason, it is important to have a process of developing creativity that can be packaged in fun teaching materials that can generate new ideas, new technology, or discoveries that refer to potentials and criteria that must be cultivated from an early age [1].

The characteristics of creativity include; (1) has a strong imagination, namely the ability to think divergent, is done without limits and is multiperspective in responding to a stimulus, (2) has initiative, children who have strong initiative will usually tend to do certain things to achieve the goals they want, (3) having broad interests, this can be indicated by the number of questions asked by children on various occasions, the child will continue to ask questions without fear and fatigue. This is done to overcome high curiosity about something he is interested in, (4) have freedom in thinking, free to think according to their experiences or fantasies without being limited by daily realities, (5) great curiosity, In general, curiosity and always curiosity are characteristics of early childhood, the enthusiasm that is owned by the child is often different from the curiosity of children so much that they do not care about their environment. This curiosity is a creative nature that encourages children to create new ideas or create new products that encourage children to answer their curiosity about something, (6) always want to have new experiences, in this case, it is often seen in children who like challenges and likes to try new things. (7) has great selfconfidence, is courageous in showing the work, and presents ideas to the surrounding environment. (8) full of enthusiasm [1].

The strategies in the field of science that can be carried out by educators to develop creativity in early childhood include; (1) creating a product, in children's work activities it will be easier to express their creative power, when children make something there will be an internalization process between imaginary power or imagination and their creative abilities, (2) through imagination, this can train basic thinking skills In terms of connecting experiences that they may have seen before with possibilities that will occur in the future, (3) exploring, exploring the surrounding environment has a very large effect on the child's creative side because this involves the child directly as an object [1].

Creativity allows a person to become a valuable individual in the environment wherever he is, as for the goals of creativity [18] namely: (1) with creativity the child can manifest himself, in other words, creativity is a form of someone who functions fully in the manifestation of it, (2) creativity is a creative way of thinking that functions to enable a person to solve daily problems, (3) busy oneself with creativity not only benefits oneself and the environment but can also provide satisfaction for creative individuals, (4) creativity serves as an enhancer of the quality of life.

Then what does science mean to develop creativity in early childhood? Creative thinking is part of creativity, where creative thinking uses the power of imagination and intelligence which moves from the original existing knowledge base to new ideas and thoughts, or it can be said to think convergent and divergent to evaluate existing to produce a new product back [10].

Many things can be done in developing early childhood creativity, in addition to models and methods, a conducive and effective, and efficient environment can also be done by packaging learning to be attractive, such as developing creativity by doing activities in simple science learning, namely jointly observing. the 
surrounding environment, for example, observing the shape of the leaves, leaf color, the height of a tree, or the color of the ground or sky. Science to early childhood aims to develop aspects of ability; (1) investigation and exploration, namely the process of observing and investigating objects and phenomena in the surrounding environment, (2) developing processes for basic scientific concepts, such as making observations, classifying, measuring and communicating the results of observations, (3) developing curiosity, being able to carry out inquiry and discovery activities, (4) understanding knowledge about various kinds of objects both in terms of structure, features or functions. On the other hand, it is stated that the importance of science education from an early age is to develop reasoning skills, analytical and critical thinking, and problemsolving. Reasoning skills are used not only to understand science but to succeed in other fields as well. analytical and critical thinking and problem-solving. Reasoning skills are used not only to understand science but to succeed in other fields as well. analytical and critical thinking and problem-solving. Reasoning skills are used not only to understand science but to succeed in other fields as well [16].

According to literature, introducing science in the early years of a child's life has strong enough reasons, because science is related to the real world and science is closely related to improving reasoning skills, by learning science one can solve simple problems in everyday life, by learning science such as observing the environment will be easy for children to get direct experience which can then be poured into the further learning process. Children are born with an intrinsic motivation to do science, in other words, even though early childhood does not receive formal science education, they have shown an effort to understand the world around them. however, children need structured guidance and learning to turn their natural curiosity and activities into something more scientific [10], [3].

Introducing the concept of science to early childhood can be done through fun games that are sourced from existing materials around the child, introducing science to children must emphasize the process rather than the product. This is because in scientific activities a child is taught to involve all the five senses as effectively as possible so that during the playing process the child can find answers to play activity. The concept of introducing science to children can be done as an effort to develop creativity by educators, one of which is by carrying out play activities such as classifying shapes, sizes, and colors that come from the surrounding environment, differentiate the types of tastes and aromas and textures of fruit that come from plants around the child, play painting or do simple experiments mixing colors using colors made and produced from plants, such as ginger, turmeric, pandan, etc. [3], [11], [6], [20].

\section{CONCLUSION}

From the explanation above, the authors conclude that cultivating creativity from an early age is very important for the growth and development of children in the future because creativity is a reflection and manifestation of an individual, with one's creativity being able to work and think creatively so that they can make their life meaningful. There are many ways that educators can foster a child's creative spirit, one of which is by stimulating it with interesting learning and games. Through the introduction of science and scientific activities, one of them, such as learning in nature, exploring, and experimenting with the surrounding environment can trigger children to think critically and creatively, not only that in science activities children will learn to respect and love nature which is inseparable from their daily life.

\section{ACKNOWLEDGMENTS}

We would like to express our gratitude to the leaders of the University of Lambung Mangkurat who have provided the opportunity administratively and teachers and parents of students who have provided sources of information related to this research.

\section{REFERENCES}

[1] Aminolroaya, Saedah et al. (2016). Methods Of Nurturing Creativity During Preschool Term: An Integrative Study. Academic Journal, Vol. 11 Issue 6.

[2] Baiti, N. (2020). Panduan Asesmen Pembelajaran PAUD dan Implementasinya. Makassar: Graha Aksara Makassar.

[3] Billah, A. (2016). Pendidikan Karakter Untuk Anak Usia Dini Dalam Perspektif Islam dan Implementasinya Dalam Materi Sains. Journal of Islamic Culture And Education, Vol. 1 No. 2.

[4] Black MM, Walker SP, Fernald LC, Andersen CT, DiGirolamo AM, Lu C, McCoy DC, Fink G, Shawar YR, Shiffman J, Devercelli AE. Early childhood development coming of age: science through the life course. The Lancet. 2017 Jan 7;389(10064):77-90.

[5] Cheng, V. M. (2019). Developing individual creativity for environmental sustainability: using an everyday theme in higher education. Thinking Skills and Creativity. ScienceDirect Journals.

[6] Dere Z. Investigating the Creativity of Children in Early Childhood Education Institutions. Universal Journal of Educational Research. 2019;7(3):652-8.

[7] Euis kurniati, R. Y. (2017). Strategi Pengembangan Kreativitas Pada Anak Usia Taman Kanak-kanak. Jakarta: Jakarta Kencana.

[8] Frith, E., Loprinzi, P., \& Miller, S. E. (2019). Role of Embodied Movement in Assessing Creative Behaviorin Early Childhood: A Focused Review. Sage Journals.

[9] Gadafi M, E. (2020). Meningkatkan Kreativitas Anak Melalui Metode Eksperimen. 
[10] Genc-Kuntape et al. (2017). Early Childhood Science Education Trends In Turkey: Where From? Where to?.. International Journal of Social Sciences, Vol.3 Issue.2.

[11] Gong, X., Zhang, X., \& Tsang, M. C. (2020). Creativity development in prechoolers: The effects of children's museum visits and other education environment factors. Studies in Educational Evaluation, 2-3. Jurnal Riset Golden Age, Vol.3 No.1.

[12] Kurniawan, H. (2017). Sekolah Kreatif. Yogyakarta: Ar-Ruzz Media.

[13] Legget, N. (2017). Early Childhood Creativity: Challenging Education In Their Role To Intentionally Develop Creative Thingking In Children. Early Childhood Education Journal, (44) 6.

[14] Moleong, L. J. (2015). Metode Penelitian Kualitatif. Bandung: PT. Remaja Rosdakarya.

[15] Mulyasa. (2016). Manajemen PAUD. Bandung: PT. Remaja Rosdakarya.

[16] Nurhayati. (2018). Pengenalan Konsep Sains Pada Anak Kelompok B TK.Pertiwi Lombe. Jurnal Smart PAUD, Vol. 1 No.1.

[17] Ria Astuti \& Thariq Aziz. (2019). Integrasi Pengembangan Kreativitas Anak Usia Dini di TK Kanisius Sorowajan Yogyakarta. Jurnal Obsesi, (3) 2.

[18] Ritter SM, Mostert N. Enhancement of creative thinking skills using a cognitive-based creativity training. Journal of Cognitive Enhancement. 2017 Sep;1(3):243-53.

[19] Susilo, S. (2016). Pedoman Akreditasi PAUD. Jakarta: Bee Media Works Pustaka.

[20] Ucus S. Exploring Creativity in Social Studies Education for Elementary Grades: Teachers' Opinions and Interpretations. Journal of Education and Learning. 2018;7(2):111-25. 